\title{
Edmund Burke e a Swinish Multitude
}

\section{Lucas Barcos Rodrigues*, Alvaro G. Bianchi Mendez}

\begin{abstract}
Resumo
Edmund Burke, em sua crítica a Revolução Francesa, utiliza o termo "Swinish Multitude" para se referir a população francesa que não teria mais um guia de conhecimento, como eram a nobreza e o clero. Partidários ingleses a Swinish Multitude começam então a escrever pamphlets e cartas em revistas em resposta a Burke, de maneira anônima, com remetente da Swinish Multitude. A pesquisa analisa então não somente essas respostas, mas também respostas de autores de mais nome a Edmund Burke, para assim traçar visão de como se davam as discussões entre esses grupos.
\end{abstract}

\section{Palavras-chave:}

Edmund Burke, Swinish Multitude, Revolução Francesa.

\section{Introdução}

Através de uma análise documental de cartas, livros e principalmente pamphlets, essa pesquisa teve como norte a análise das relações e discussões que se apresentavam na relação entre Edmund Burke, uma classe mais alta de autores que discutiam com o mesmo acerca da Revolução Francesa e a "Swinish Multitude", título dado pelo próprio Burke a população francesa que pós-revolução se tornariam esse grupo de "porcos" sem ninguém para guiar e disseminar conhecimento entre eles, anteriormente função da nobreza e do clero. Para assim traçar a maneira que se davam essas relações e principalmente os assuntos dessas discussões.

\section{Resultados e Discussão}

Inicialmente, cabe trazer a metodologia utilizada nessa pesquisa, que foi que de importância crucial para que qualquer análise pudesse ser feita. Foi utilizada a metodologia proposta por Quentin Skinner ${ }^{1}$, que visa analisar para além do que está somente escrito na obra, buscando entender quais eram de fato as intenções do autor ao escrever sua obra. Ao se procurar entender o que o autor quis dizer, compreendendo seu tempo histórico específico, ou seja, as lógicas e razões que faziam sentido no período que a obra foi escrita, sem ter a influência de escritos e respostas posteriores a obra, se é capaz de obter um real entendimento dos sentidos da obra e fazer uma análise que não caia em anacronismos.

Com isso, é necessário partir da obra de Richard Price ${ }^{2}$, que foi uma grande inspiração para que Edmund Burke ${ }^{3}$ fazer sua resposta que origina o termo "Swinish Multitude". Em sua obra, Price exalta três pontos cruciais de serem vistos, a questão da liberdade, do conhecimento, e da virtude. O conhecimento é necessário para se retirar o homem da escuridão, porém atrelado ao conhecimento é necessária a virtude, caso contrário esse homem se tornaria problemático. Porém para que esses fossem obtidos e espalhados, a liberdade era uma questão crucial e absolutamente necessária, e a mesma seria impossível de ser alcançada em um estado que a população era obrigada a se rebaixar mediante aos déspotas que estavam no poder, e inverter esse quadro é não mais que a obrigação da população para sair de um estado de escuridão e alcançar um estado de clareza e liberdade.
Esses princípios exaltados por Price são os pontos de defesa da Revolução Francesa, e são esses princípios que Edmund Burke discute em sua obra, pois para Burke, a revolução em vez de trazer tal estado de esclarecimento e liberdade traria senão um estado de escuridão e não disseminar do conhecimento, pois era função das instituições já estabelecidas historicamente como disseminadoras de conhecimento. As respostas vindas da Swinish Multitude vão contra o que diz Burke, ressaltando não só o caráter despótico que assumiam essas instituições, como criticando de maneira irônica as visões que são colocadas por Burke, nomeando, por exemplo, tais instituições tão exaltadas de chiqueiros luxuosos para porcos de luxo, enquanto que eles não somente não eram capazes de adentrar ao chiqueiro.

\section{Conclusão}

Assim, a pesquisa abordou esses e outros pontos de discussão que se apresentavam nesses pamphlets e livros, que demonstravam toda a realidade histórica a ser entendida, mediante a metodologia empregada, para que seja possível o mapeamento dessas relações entre os diferentes atores da época, compreendendo não só seus pontos de vista acerca dessa discussão, mas a maneira que adentravam e argumentavam tais assuntos.

\section{Agradecimentos}

Agradecimentos a Cnpq pelo financiamento dessa pesquisa. Agradecimentos também a Álvaro Bianchi como orientador desde a origem até a finalização desse projeto.

${ }^{1}$ SKINNER, Quentin. Visões da política: sobre os métodos históricos. Lisboa: Difel, 2005.

${ }^{2}$ PRICE, Richard. A discourse on the love of our country, delivered on Nov. 4, 1789 , at the meeting-house in the Old Jewry, to the Society for commemorating the revolution in Great Britain. With an appendix, containing The Report of the Committee of the Society; an Account of the Populations of France: and the Declaration of Rights by the National Assembly of France. Second edition. By Richard Price, D.D. LL.D. F.R.S. And Fellow of the American Philosophical Societies, at Philadelphia and Boston. Printed for Messrs. H. Chamberlaine, P. Byrne, L. White, Grueber and Maállister, J. Jones, J. Moore, and W. Jones, M,DCC,XC. [1790]. Eighteenth Century Collections Online.

${ }^{3}$ BURKE, Edmund. Reflections on the Revolution in France, and on the proceedings in certain societies in London relative to that event. London. The tenth edition. 1791. In Collection Queen's University Library. 